\title{
Systemic Processes in Families of Adolescent Addicts
}

\author{
Petar Nastasić \\ ECPD University for Peace and Development, Belgrade
}

\begin{abstract}
Experimenting with drugs in the period of adolescence is today spread world widely. The linear, single-factor, or the deterministic method offer explanations of the nascence of the abuse of psychoactive substances (PAS) that include the effects of these factors: biological processes, inter-psychological processes or various characteristics of the very children, their parents, peer groups or the social environment. This method is therefore largely substituted with circular, interactive - multisystem models. The use and abuse of PAS usually appears as an essential part of the wider picture of life conditions and circumstances, therefore a systematic conceptualization of the issue and its therapeutic solution is indeed called for. Working on this issue, we are considering systematic characteristics of the family of adolescent addict, analyzing their influences on the process development of the treatment in general, and pointing out the implementation of family therapy.
\end{abstract}

Key words: Dependence on psychoactive substances in adolescence, systemic characteristics of the adolescent addict's family, the model of social interactionism, family therapy of adolescence addictions

Copyright (C) 2018 KBCSM, Zagreb

e-mail: alcoholism.kbcsm@gmail.com•www.http://apr.kbcsm.hr

\section{Introduction}

The use of psychoactive substances (PAS) and forms of its expressions are increasingly becoming a wide-spread fact, connected with the adolescence as a common rule. This connection, in contemporary life conditions, is becoming almost epidemic - the incidence is growing, firmer and clearer as ever. The very beginning, process and the duration of the

Correspondence to:

ECPD University for Peace and Development

Terazije 41

1100 Belgrade, Serbia

Email: p.nastasic@gmail.com abuse and/or addictions on PAS during adolescence can be observed as the existence of a certain type of continuum (from - "zero use" to "heavy addiction").

Experimenting with drugs in the period of adolescence is a widely-spread occurrence. Looking at the epidemiology data [1,2] 50\% of adolescents, aged 19, used cannabis; $20 \%$ of them tried various "street drugs" (dissolvent, glues, stimulating drugs, hallucinogens, opiates; $20-40 \%$ use two types of drugs, or more. According to the same data source, $5 \%$ - $10 \%$ of teenagers under the age of 19 have drug related problems which are severe to the 
extent that clinical interventions must be applied.

The single-factor, linear or the deterministic model offers explanations of the occurrence of the PAS abuse looking at the effects of previously mentioned, single factor: biological processes, inter-psychological processes or various characteristics of children, their parents, peer groups or their social environment. Therefore it was widely substituted with circular, interactive, multi-systemic models [3].

The early, now considered as classical descriptions of the development of the PAS abuse in Western societies point out at the progression starting with the early use of tobacco and alcohol, going step-by-step to the level of the problematic abuse of alcohol, then cannabis use, and at the end, we arrive to the level of multiple abuses and the development of multiple addictions [4-6]. All adolescents, fortunately, do not necessarily and inevitably go through this unfortunate gradation of PAS abuse.

Every day, or a regular use of PAS in adolescence can indeed have very significant negative effects on the adolescents and their relationships with the family and wider environment. Since this is not a one-dimensional process, consequently all the problems deriving from them are far from simple and easy to resolve. The PAS use and abuse usually occurs as a building-block of a wider picture of life circumstances and difficulties, therefore a systemic conceptualization of this issue and its therapeutic intervention [3] is imminently needed and urgently called for.

Peer groups in this period of youth have an extreme appeal and substantial significance for adolescents, because they form a certain context for the advancement through- out their psychosocial development (having moral decisions, balancing between the autonomy/individualism and responsibilities, firming and integrating the self-identity). The inner structure of peer groups, per nature existing as primary groups, relies on the principles of adolescent emotionality (closeness, solidarity), but certain parameters from the adult group are embedded in it (hierarchy, power, valorization and its importance, rules of advancement in the group). Many adolescents see a peer group and "buddies from the group" - as a shield, or a saving rope, the last resort, so losing the position in the peer group or the request of parents to be alienated from these "friends" may surely appear to them as a frightening thought $[5,6]$.

However, children and adolescents aren't often ready or capable to make a free choice of their peer group. It may happen that they face rejection from the desirable or the "straight peer group", so those adolescents may seek approval from the groups prone to deviations such as SAP. It's often the consequence of existing conflicts in the family, so those adolescents can face great difficulties wishing to belong to their preferred peer group.

Limited and poor-quality relationships between adolescents and their parents, extremely rare support and the lack of monitoring of their activities and emotional/mental states by the parents, a non-consistent use of the punishment system, or the complete disorganization of the family of any kind - unclear and non-defined rules or everyday routines - are some of the predispositions from the family circle aspect which increase the risk for the occurrence of adolescent PAS abuse. Those factors can include psychological problems or marital discordance/disputes, or the presence of a problematic sibling, prone to socio- 
pathic behavior or PAS abuse also. What is really important is the reaction of the family when PAS abuse is detected from the start, such as: expressing a positive attitude about PAS using, as well as the lack of a clear and consistent antagonistic behavior and banning the PAS use as a direct and strong reaction. In such family context, the increase of PAS abuse/addiction is encouraged.

Even parents that lack accurate and full knowledge concerning adolescent PAS abuse as well as the solutions to the problem can contribute, unfortunately, to the increased abuse of their children.

Ergo, the families of adolescents that developed the addiction appear as a very important as well as a present, an indeed essential part of the problem, a factor that is partially responsible for the occurrence of the PAS abuse [7, 8].

Of course, none of the factors and hypothetical situations mentioned above do not act as the unique factor, or in the linear manner, but only through their various and unpredictable interactions.

The occurrence of the curiosity concerning psychoactive substances and the beginning of their use in adolescence can be analyzed from the point of view of social interactionism, Gerald Patterson [9-11].

Having in mind emotional particularities of the adolescence and the need for bonding, then the development of, very often, an antagonistic interaction between the family and the peer group, we can recognize the creation of a valuable context in which the adolescent is torn between two groups and strong aspects of social adapting and learning. The very use of psychoactive substances derives from this very context. Peer group myths and gossips about the effects of psychoactive sub- stances as well as the strong desire to belong to the peer group, along with "so appealing expected effects", ensure the necessity to belong to the peer group. Therefore, psychoactive substance and its use/abuse appear only as one of multiple factors that would ensure the dynamics of all the levels of a specific social interaction, which will result with the social behavior disorder. In other words, we are talking about the synchronized integration of antagonistic sequences of family and social interactions of the adolescent using PAS with his own cognitive development, especially accentuated with emotional turmoil's. As a matter of fact, the conditions are, in real life, marked by the cognitive, especially emotional disequilibrium found in adolescents [11].

The symptom as the abuse or addiction on the psychoactive substance appears as a systemic adaptation of the adolescent to the total of the context of his life, and has the function to maintain the homeostasis of his adolescent system. This system will maintain the adolescent's symptom, because he manifests certain symptomatic behaviors and has certain symptomatic reasoning or beliefs. It's possible because he lives in his system of communication, in which similar thoughts and behaviors are adequate and acceptable [6]. Putting a stop on those symptoms of adolescent dysfunction isn't possible without the change in the very same communication system. Therefore, when PAS use/abuse begins and lasts for a period - the development and creation of adolescent addiction has a predictable path, with the treats of continuum, but it's not at all a uniform nor a linear phenomenon: there are heterogeneous forms of manifesting the clinical picture of the dependency and heterogenic characteristics of the families of adolescent addicts [3]. 
Clinical implications deriving from the facts mentioned above are: there is a strong connection between normal steps of going through the adolescence and the initial abuse of psychoactive substances. On the other hand, use and abuse of psychoactive substances have an undeniably destructive impact on mentioned steps of the development of an adolescent.

Completely in accordance with these statements is also Baley's standing-point, who states:

- All the children as well as adolescents are living under the risk (of commencing the abuse of substances), but some of them are significantly more exposed to that risk than the others [12].

This, almost imminent risk can be related to the existence of a primary psychic disorder of an adolescent, but much more frequently includes the treats of the family and broader social environment.

Multi-systemic, complex models consider and point out to the abuse of psychoactive substances as the occurrence grown from the vulnerable adolescent, implicated in problematic family relationships, problematic peer group relations inside the social community or the environment where PAS are easily available, and the possibilities for other means for the self-accomplishment are unfortunately blocked $[3,13]$.

After the initial period, the adolescent starts to use PAS more regularly, suffering from signs of physical and psychological dependency, including psychological abstinence crisis (lighter or more intense variations). He wants now to minimize those negative states of mind that arise from physical as well as psychological disturbances and financial needs...the lack of money, school grades go- ing down, potential and most probable varieties of delinquency etc. What particularly encourages the maintenance of the progress towards more frequent abuse and dependency is, of course, all that the addicts way of thinking constitutes of - the typical adolescent narrative using PAS, based on the conviction that he can successfully be in control when using drugs, that problems, in fact, don $t$ exist, and if they exist at all, they are nor hard or dangerous, because there is no dependency whatsoever. Even if it exists, it is so light and insignificant that it's not worth talking about.

We are talking about the events and opinions forming as a result of a changed neurobiochemistry and wrong emotional development/learning [6].

\section{Systemic treats of families of adolescent addicts}

There are significant difficulties and limitations in the process of creating consistent findings concerning the families with adolescent addicts, because all gathered knowledge is mostly based on observations and studying the families that voluntarily accept the treatment $[3,6,7,13]$.

Kauffman [14] considers that there is a logical assumption those families, regarding their structure, are implementing more networking between themselves, then those that refused the treatment. According to our experiences this assumption is correct, above all because of the amplified tendency of the addict-families and marital dyads towards the fusion and following domination of the emotional aspect and the amplified need for togetherness [15].

In the same manner, the findings of Reily, according to the citation of Carr [3] in which 
the negatively deduced interactions are emphasized (family members are involved in negative interactions such as criticism, judgment, offenses, complaints, constant grunting...). The limitation setting or structuring implemented by the parents is not consistent and often contradictory in its effectiveness. This is related with the attitude that very often, the admission of the abuse or addiction, as well as other problems that an adolescent may have, is viewed as a typical "cry for help", need for attention in order to obtain some kind of reaction, structure and needed limitations from the parents.

There could be also a presence of the abuse of alcohol or other PAS substances for self-medication in the family, in order to spur the emotional expressions or acting-out certain reactions (destruction, violence), because of many difficulties in expressing disagreements, anger, rage, - so, all of this is expressed by staying silent, or by violence/ physical abuse, which represents a typical interactive pattern in addict-families. According to Reily, (ibid), what is characteristic is the pattern of pathological expectancies from the child, in which the treats (in an obvious, or symbolic way), good or bad, of a certain relative: grandmother/grandfather or another member of the family is recognized; therefore this child is not perceived and accepted realistically, as it truly is. It indicates a strong parental projection and lowered differentiation of the parent - self-awareness.

The appearance of a specific "unbelievable reasoning and verbalizing" that consists of statements full of promises to change the behavior in the future, completely unrealistic, often very unclear or not at all understandable, seem unlikely to be accepted as believable, because these statements simply - do not mean what is actually said.
Further on, we will talk about formulating opinions concerning systemic characteristics of the family of the adolescent addict [3] aside from classic systemic concepts about the very adolescent/addict being the bearer of the family dysfunction, and that he actually enables the sustainability of the family pathological homeostasis, encouraging the need of his parents for control and the continuation of parenting process, even if the very adolescent/addict believes this kind of parenting is absolutely inadequate. The source of such a homeostatic balance is found in the triangulation of the child. We are talking about parents avoiding their own conflicts, having a problematic child as an excuse. Instead of resolving their marital or parental disagreements, or the dissatisfaction with one another, therefore resolving the obstacles for the parents to create a united parenting team, they, as parents, have chronically unconvincing and non-consistent attitudes towards the attempts to resolve and control problems connected to adolescent problems, including the PAS use/abuse.

In those circumstances the adolescent may be detected in a hidden coalition with one parent against the other (the child can "sell" its affection in order to smoothly maintain the abuse). This behavior pattern as well as family organization can be partially initiated with personal psychological problems that parents are suffering from. The very adolescent provides the shift of the "battlefield", in a way that implicitly as well as explicitly misbalanced marital relations of his parents and their conflicts seem not to exist, or to be visible. Forming a cross-generational alliance with which a child separates his parents one from another leads to intergeneration boundaries to be diffused - that often creates the atmosphere of competition between 
the parents. Crisis created by the PAS abusing adolescent appear to be the only way for the family to be in a way "really coherent and together" in order to solve a certain problem, because it seems this can often create the unique opportunity for the "dead marriage" or "non-existent family" to get back on their feet and go ahead in a more optimistic manner.

\section{Families of adolescent PAS abusers and the Process of the Treatment}

The first, most common and lasting thoughts and sentiments that can be perceived in the families of adolescent PAS abusers are - negating. ("No, my child has nothing to do with that!). The fact that their child is using drugs is accepted by many parents with a lot of emotional pain, the process is very hard, and it may indeed include the sense of their guilt. This pain is an addition to the existing emotional complexity of family/parental reaction, which, of course, makes the solution of the problem even more difficult.

Many parents remain convicted that they raised their children with lots of love and as great role-models, always supporting them, so they believe their children should have developed their personal values as well as selfconfidence, that ought to encourage resisting the pressure of the peer group using drugs, therefore their reaction is stronger, and the pain all the more overwhelming.

Parents may fall in the reassuring trap of believing that "the child" took the drugs (as an extremely undesirable, but "one-time only" kind of incident), but they are unable to face it or accept it. During the phase when the problem wasn't yet in the open, - in our experience-, adolescents recognized this negation as parents unease to be faced and ex- posed to the fact their child is using/abusing PAS. Therefore, the first response of the young, adolescent drug addict is to deny the very existence of the problem, even when he, in his very intimate thoughts about it, in fact hopes and relies on the parents, and the logical events that are supposed to happen - parents will discover the abuse and seek treatment.

The result of this negation of the problem is perceived as the "system delay".

The problem of PAS use/abuse found in adolescents has become truly serious long before the parents took any action at all; either through family regulatory mechanisms, or through asking for help from the professionals.

The "system delay" is very understandable from the position of an existent, strong homeostatic mechanism in marital or parental subsystem.

Involved in unresolved dilemmas in their relationship, or eventual conflicts, parents weren't able to "sense" crucial moments of the internal processes and the "emotional climate" in the family started to deviate and approach unacceptable changes, as far as possible from the "normal", let alone optimal family climate. Their relationship as well as the one with the adolescent is therefore, distortedly, viewed as correct and "as usual", not even thinking about changing a thing $[6,15]$.

An awakened and stressed-out pair mother and father -, as well as the whole family, beginning the game of " medical detectives" - looking for answers concerning the very beginning of the problem, exposing lies, searching for the responsible/guilty one, mutual accusations. It triggers an avalanche of painful self-reflections, furthermore feelings of unexpressed love, sense of involve- 
ment. Then, an obsession over the problem may occur, sorrow, disappointment, despair, concern for the health and the future of the child. Other parents are overwhelmed with anger, confusion, even hostility towards their child (because of the lying, cheating on established rules, abusing drugs). Negative emotions and hostility among the members of the family in some cases are created and cultivated for years. In fact, what is happening is "the encounter", filled with built-up emotional reactions, along with angry words, accusations and counteraccusations.

Scenes such as those might result with further deterioration of communications in the family, with the obvious possibility to worsen, unless they are recognized and a serious treatment is asked for.

In the first phase of the treatment parents have positive, as well as negative feelings towards their adolescent, the PAS abuser. They want to protect their child, care for it, show their love and be concerned about their welldesigned future. However, at the same time, the parent can be very angry and sense even hostility towards their troubled child, looking to get rid of problems, responsibility, burden and efforts as soon as possible, because the treatment could indeed provoke that reaction.

Often the parents seek magical solutions - easy, efficient and speedy ones, as if they are following the typical "principle of satisfaction of an addict".

Many of them fell it isn't appropriate to let those feelings sink in; when, possibly, they even recognize they basically want to get rid of their own child, they aren't capable of facing it, nor to "work" on the fact that they are responsible for being in charge, detecting and shifting those feelings in an open, honest and constructive way. Sometimes it seems they aren't able to verbalize only their positive feelings and their interest for the child yearning for such expressions of love and caring, a child in essential need of getting this kind of reaction, a "curative" one, from the parents the positive/oriented one. Children are very sensitive to negative feelings and reactions, prone to recognize and mimic/adopt them in a blink of an eye.

The parental sense of guilt and typical self-accusations such as - "This must be my fault - I am the parent" - creates in general a certain feeling of helplessness, making them virtually incapable to anything at all.

So, this feeling isn't therapeutically usable, because if the parent confesses his feelings to his child, that will relieve him partially of his own sense of guilt, but it certainly won't help the child to change his behavior and stop taking drugs. Feelings of guilt and self-accusation aren't necessary for the progress to be achieved. What is needed is a non-accusatory, but at the same time non-defensive attitude towards the problem and oneself.

On the other hand, some parents don't accuse themselves at all, because - either they are trying to grasp the problem in a calm and objective manner, -or we are dealing with the individuals that are avoiding responsibility and the basic moral sense, always accusing someone or something else (the society, school, police, their own child). The feeling of guilt is for them very unpleasant, painful and unacceptable, automatically defending themselves from the experience of sensing the burden of guilt.

In the family systemic therapeutic concept, evaluation of the real quality of relationships in the family itself and the preservation of open discussion with the adolescent/ 
drug abuser is much more important than the process of discovering true reasons and the magnitude of the symptom/problem. The results of the therapy relies also on new, open and constructive communications within the family - if these relationships aren't irreparably destabilized and there is a chance to change the family dynamics for the better, it isn't necessary to go further with the "medical detective" game, or "the policeman", even medical professionals sometimes cannot resist. The best solution could be for the parents to cultivate the openness in their way of thinking and reach the point of objectivity related to the problems and ways to resolve them.

It is crucial for the parents to realize in which way they, in fact, attributed to the very occurrence of the problem that lead the adolescent to be seriously involved in drug addiction... However, it's far from easy for the family to explore ways of their involvement into a non-intentional approval of drug use (and all the damage done during the duration of the abuse) in an objective

\section{References:}

1. Inman DD, van Bakergem KM, LaRosa AC, Garr DR. Evidence- based Health Promotion Programs for Schools and Communities. Am J Prev Med. 2009;2:207-19.

2. Towey K, Fleming M. Policy and Resource Guide: Alcohol Use and Adolescents, Chicago,IL: American College of Preventive Medicine and American Medical Association National Coalition for Adolescent Health 2006.

3. Carr A. Family Therapy: Concepts, Processes and Practice. New York: John Wiley\&Sons; 2006.386404.

4. Elkin M. Families Under the Influence. New York: W.W. Norton Press; 1994. manner, or to miraculously come up with a way to mend in a second what has, unfortunately, happened.

At the same time, a therapist should hold several séances with the parents without the adolescent/abuser, or siblings present, in order to help the couple to draw a circle around their marital system, regardless of its characteristics, so that the married couple can plan activities and the time spent together without the children present.

The goal is to amplify the mutual support among parents and, above all, to de-triangulate the adolescent that could be seriously stuck in this uncomfortable position "to be in between, torn in two", with one parent relying and believing more in him for support then on his own life partner.

\section{Acknowledgement}

None

\section{Conflict of Interest}

None to declare
5. Nastasic P. Sindrom zloupotrebe/zavisnosti od vise psihoaktivnih supstanci kod adolescenata U. Milovanovic, D. Sakoman, S Dimitrijevic i urednici, Bolesti zavisnosti. Beograd: ECPD;2011. 18699.

6. Nastasic P. Bolesti zavisnosti u adolescenciji. Beograd: Publikum;2011, 96.

7. Furstenburg FM. The Sociology of Adolescence and Youth in the 1990-ties: A Critical Commentary. J Marriage Fam. 2004;62:896-910.

8. Addiction Medicine at Talbot Hall. Substance Abuse/Chemical Dependency. The Ohio State University Medical Center. Accessed Mar.9, 2011 from http//www.casacolumbia.org/articlefiles/ 380-ShovellingUpII.pdf. 
9. Hrnčić J. Delikvent ili pacijent, studija porodičnog neuspeha. Beograd: Zadužbina Andrejević; 1999.

10. Hrnčić J. Prestupništvo mladih: rizici, tokovi i ishodi. Beograd: Institut za kriminološka i sociološka istraživanja; 2009.

11. Patterson G.R., DeBaryshe B., Ramsey E. A developmental perspective on antisocial behavior. Am. Psychol. 1989;44:329-35.

12. Schuckit MA. Drug and Alcohol Abuse: A Clinical Guide to Diagnosis and Treatment. New York: Kluwer Academic Plenum Publishing, 2000.
13. Barrett A.E., Turner J.R. Family structure and substance use problems in adolescence and early adulthood: examining explanations for the relationship. Journal of Child and Adolescent Substance Abuse. 2005;5;1-19.

14. Kaufman, E. Adolescent substance abusers and family therapy. In: Friedman, A.S., and Granick, S., eds. Family Therapy For Adolescent Drug Abuse. Lexington, MA: Lexington Books,.1990a; pp. 47-61.

15. Nastasić P. Alkoholizam i međugeneracijsko prenošenje.Beograd: Tehniss; 1998.

\section{Sistemski procesi u obiteljima adolescenata ovisnika}

Sažetak - Eksperimentiranje s drogama u periodu adolescencije je danas rašireno u svijetu. Jedan linearni faktor ili deterministička metoda nudi objašnjenje početak stvaranja zlouporabe psiho-aktivnih supstanci (PAS) koje uključuje efekte sljedećih faktora: biološki procesi, inter-psihološki procesi, ili razne karakteristike spomenute djece, njihovi roditelji, grupe vršnjaka ili društvena okolina. Ova metoda je većinom zamijenjena kružnom, interaktivnom-multi-sistemskom metodom. Korištenje i zlouporaba PAS-a se uglavnom pojavljuje kao nužni dio šire slike životnih uvjeta i okolnosti, zato su sistemska konceptualizacija problema i njegova terapeutska rješenja potrebna. Radeći na ovom problemu, razmatramo sistematsku karakterizaciju obitelji adolescenata ovisnika, analiziramo utjecaje na proces razvoja tretmana uopće, i ističemo implementaciju obiteljske terapije.

Ključne riječi: ovisnost o psiho aktivnim supstancama u adolescentskoj dobi, sistemske karakteristike obitelji adolescenta ovisnika, model društvenog interakcionizma, obiteljska terapija adolescentske ovisnosti 
